Gabrijela Popović ${ }^{1}$

Bojan Đorđević ${ }^{2}$

Dragan Milanović ${ }^{3}$
JEL: C44, D81, L23, L72

DOI: $10.5937 /$ industrija47-24128

UDC: 005.21:622(497.11)

005.311:519.226

Original Scientific Paper

\title{
Multiple Criteria Approach in the Mining Method Selection ${ }^{4}$
}

\author{
Article history: \\ Received: 22 October 2019 \\ Sent for revision: 7 November 2019 \\ Received in revised form: 25 November 2019 \\ Accepted: 26 November 2019 \\ Available online: 31 December 2019
}

\begin{abstract}
Underground mining method selection is a very complex task for the mining engineers because the chosen method should fulfill the technical, economic and production requirements. Combining the criteria that cover different aspects of the mining operation and group decision-making increases the reliability of the decisions and minimize its subjectivity. The main objective of this paper is to propose the methodology for the underground mining method selection based on the Extended Pivot Pairwise Relative Criteria Importance Assessment (PIPRECIA-E) and group decisionmaking. The applicability of the proposed methodology is demonstrated by using the numerical example inclusive of 3 main criteria, 18 sub-criteria and 5 alternative underground mining methods pointed to the exploitation of the Upper Zone of the Čukaru Peki deposit in Serbia.
\end{abstract}

Keywords: Multiple-Criteria Decision-Making, PIPRECIA-E, group decisionmaking, underground mining method selection, Čukaru Peki.

\section{Višekriterijumski pristup izboru metode rudarenja}

Apstrakt: Izbor metode za podzemnu eksploataciju predstavlja veoma kompleksan zadatak za rudarske inženjere zato što izabrana metoda treba ispuniti tehničke, ekonomske $i$ proizvodne zahteve. Uključivanje više

\footnotetext{
1 Megatrend University, Faculty of Management in Zajecar, gabrijela.popovic@fmz.edu.rs

${ }^{2}$ Megatrend University, Faculty of Management in Zajecar

${ }^{3}$ Mining and Metallurgy Institute Bor

${ }^{4}$ The paper is a part of a research conducted on the project under the code TR 33023, financed by the Ministry of Education, Science and Technological Development of the Republic of Serbia.
} 
Popović G. et al.: Multiple criteria approach in the mining method selection

kriterijuma koji uzimaju u obzir različite aspekte rudarske proizvodnje kao $i$ grupno odlučivanje doprinosi povećanju pouzdanosti odluka i smanjenju subjektivnosti. Osnovni cilj ovog rada je predlaganje metodologije za izbor metode podzemne eksploatacije bazirane na PIPRECIA-E metodi (Extended Pivot Pairwise Relative Criteria Importance Assessment) i grupnom odlučivanju. Primenljivost predložene metodologije prikazana je pomoću numeričkog primera koji uključuje 3 osnovna kriterijuma, 18 podkriterijuma i 5 alternativnih metoda podzemne eksploatacije planiranih za primenu u Gornjoj zoni ležišta Čukaru Peki u Srbiji.

Ključne reči: Višekriterijumsko odlučivanje, PIPRECIA-E, grupno odlučivanje, izbor metode rudarenja, Čukaru Peki.

\section{Introduction}

One of the most important and requiring decisions that mining engineers have to make is certainly a selection of the underground mining method. The ore production, lost rate, safety and overall production productivity (Liu, Dong, \& Dong, 2010) depend on the chosen mining method. Decisions connected to this kind of problem are characterized by a lack of geological information and uncertainty which complicates the decision-making process and leads to the final decisions that are often subjective.

Ensuring the optimal use of underground resources is the main goal of the mining method selection (Alpay \& Yavuz, 2007). Besides, the selected method should enable the obtaining of the maximum profit, low excavation cost, and safe working conditions for the miners (Ataei, Jamshidi, Sereshki, \& Jalali, 2008; Bogdanovic, Nikolic, \& Ilic, 2012). Generally, each of the available methods is followed by certain issues and the one which brings the least number of problems could be considered the optimal method.

In order to obtain an optimal decision, all relevant criteria should be involved in the underground mining method selection process. The greater number of criteria important for the evaluation will certainly complicate the decisionmaking but gained results would be more accurate and reliable (Naghadehi, Mikaeil, \& Ataei, 2009). Basing the selection on only one factor or on the intuition of one person would lead to inadequate decisions.

The fact that the underground mining method selection should be based on the greater number of evaluation criteria contributes to the conclusion that the Multiple-Criteria Decision Making (MCDM) methods are suitable for the application in this area. MCDM represents a field of management science and operational research that has significantly developed in recent years and enabled easier resolving of many business problems. A good overview of the 
introduced MCDM methods could be found in the papers of the following authors: Velasquez \& Hester (2013), Zavadskas, Turskis, \& Kildienè (2014) and Mardani et al. (2015). Different combinations of these methods are used in resolving various business and optimization problems (Pamučar, Lukovac, Božanić, \& Komazec, 2018; Milosavljević, Bursaća, \& Tričković, 2018; Vesković, Stević, Stojić, Vasiljević, \& Milinković, 2018).

Until today, many scientists dealt with the question of the underground mining method selection by using different MCDM methods. Mahase, Musingwini, \& Nhleko, (2016) give a good overview of the MCDM methods applied in the area of mine planning and similar cases. According to the current situation, the Analytic Hierarchy Process - AHP (Saaty, 1980) represents the technique that is very popular and widely used for the mining method selection (Ataei et al., 2008; Alpay \& Yavuz 2009; Gupta \& Kumar, 2012; Yavuz, 2015a). Also, the combination of the MCDM methods as well as the fuzzy extensions of the methods are very often applied for the same purpose (Bitarafan \& Ataei, 2004; Karadogan, Kahriman, \& Ozer, 2008; Samimi Namin, Shahriar, AtaeePour, \& Dehghani, 2008; Bogdanovic et al., 2012; Ataei, Shahsavany, \& Mikaeil, 2013; Karimnia \& Bagloo, 2015).

The main aim of this paper is to point out the advantages of the PIPRECIA-E method (Stanujkic, Zavadskas, Karabasevic, Smarandache, \& Turskis, 2017), which is especially suitable for application in the group decision-making environment. The applicability of the proposed methodology is presented by the numerical example that involves 3 decision-makers (hereinafter marked as DM), 3 main criteria, 18 sub-criteria, and 5 alternative mining methods. The central goal is defining the optimal mining method which will be used for the exploitation of the Upper Zone of the Čukaru Peki deposit.

Except for the Introduction and the Conclusion, the rest of the paper is organized as follows: in the second part the proposed methodology is explained and in the third part the numerical example which contains the application of the proposed methodology is presented, as well as the gained results discussion.

\section{Methodology}

In this case, for resolving the mining method selection problem PIPRECIA-E technique, introduced by Stanujkic et al. (2017), is proposed. The starting point for the creation of the mentioned method was SWARA method (Keršuliene, Zavadskas, \& Turskis, 2010). Namely, the PIPRECIA-E retains the good features of SWARA method and overcomes its deficiencies. The SWARA method is not very suitable for group decision-making because its procedure requires pre-sorting of the considered criteria, that complicates the 
Popović G. et al.: Multiple criteria approach in the mining method selection

consolidation and determining of the final results. Besides, SWARA method does not anticipate checking the consistency of gained results, which is a part of the procedure of well-known AHP method (Saaty, 1980).

Contrary to SWARA method, the PIPRECIA-E method does not require the previous sorting of the evaluation criteria, which makes it more suitable for the application in the group decision-making environment. PIPRECIA-E implies consistency testing by applying Pearson's or Spearman's correlation. Additionally, the PIPRECIA-E method predicts the bidirectional approach which includes the evaluation of the considered criteria in both directions, i.e. from first to the last and vice-versa. This way of criteria estimation is somewhat complex, but the obtained results are more reliable because decision-makers must thoughtfully perform the evaluation which also contributes to the consistency of the final results.

Until now, PIPRECIA-E method was used for the assessment of tourism projects (Popović, \& Mihajlović, 2018). PIPRECIA method, that is an integral part of the PIPRECIA-E method, is used for evaluation of the websites' quality (Stanujkic, Karabasevic, \& Cipriana, 2018), consumer satisfaction of the restaurants services (Stanujkic, Karabasevic, Zavadskas, Smarandache, \& Cavallaro, 2019a), and the fuzzy extension of the PIPRECIA method is recently proposed (Stević, Stjepanović, Božičković, Das, \& Stanujkić, 2018). All of this indicates that the possibilities of the PIPRECIA-E method are not fully tested yet.

The numerical procedure, used in this paper, relies on that one presented in the paper of Stanujkic et al. (2017) and could be illustrated by the following series of steps.

Step 1. Selection of the evaluation criteria where presorting is not obligatory.

Step 2. Determination of the relative importance $s_{j}$ that begins from the second criterion as follows:

$s_{j}=\left\{\begin{array}{ccc}>1 & \text { when } & C_{j} \succ C_{j-1} \\ 1 & \text { when } & C_{j}=C_{j-1} \\ <1 & \text { when } & C_{j} \prec C_{j-1}\end{array}\right\}$.

Step 3. Definition of the coefficient $k_{j}$ in the following way:

$$
k_{j}=\left\{\begin{array}{cc}
1 & j=1 \\
2-s_{j} & j>1
\end{array}\right\} .
$$

Step 4. Detection of the recalculated value $q_{j}$ as follows: 
Popović G. et al.: Multiple criteria approach in the mining method selection

$q_{j}=\left\{\begin{array}{cc}1 & j=1 \\ \frac{q_{j-1}}{k_{j}} & j>1\end{array}\right\}$.

Step 5. Determination of the relative weights of the estimated criteria by using the following Eq.:

$w_{j}=\frac{q_{j}}{\sum_{k=1}^{n} q_{k}}$,

where $w_{j}$ represents the relative weight of the criterion $j$.

Step 6. Definition of the inverse relative importance $s_{j}^{\prime}$ starting from the penultimate criterion in the following manner:

$s_{j}^{\prime}=\left\{\begin{array}{ccc}>1 & \text { when } & c_{j}>c_{j+1} \\ 1 & \text { when } & c_{j}=c_{j+1} \\ <1 & \text { when } & c_{j}<c_{j+1}\end{array}\right.$.

Step 7. Determination of the inverse coefficient $k_{j}^{\prime}$ by using the following Eg.:

$k_{j}^{\prime}=\left\{\begin{array}{cc}1 & j=n \\ 2-s_{j}^{\prime} & j<1\end{array}\right.$.

Step 8. Definition of the inverse recalculated weight $q_{j}^{\prime}$ as follows:

$q_{j}^{\prime}=\left\{\begin{array}{cc}1 & j=n \\ \frac{q_{j+1}^{\prime}}{k_{j}^{\prime}} & j<n\end{array}\right.$.

Step 9. Determination of the inverse relative weights of the considered criteria in the following way:

$$
w_{j}^{\prime}=\frac{q_{j}^{\prime}}{\sum_{k=1}^{n} q_{k}^{\prime}},
$$

where $w_{j}^{\prime}$ is the inverse weight of the criterion $j$.

Industrija, Vol.47, No.4, 2019 
Popović G. et al.: Multiple criteria approach in the mining method selection

Step 10. Verification of the reliability of the obtained results by using the Spearman's rank correlation coefficient:

$\rho=1-\frac{6 \sum_{i=1}^{n} d_{i}^{2}}{n\left(n^{2}-1\right)}$,

where $\rho$ represents the correlation coefficient, $d_{i}$ is a distance between the ranks for every $x_{i}, n$ denotes the number of elements in each data series and $\rho \in[-1,1]$.

Step 11. The overall weight $w^{\prime \prime}$ of the criteria is calculated by applying the Eq. (10):

$w_{j}^{\prime \prime}=\frac{1}{2}\left(w_{j}+w_{j}^{\prime}\right)$,

where $w_{j}^{\prime \prime}$ represents the final weight of the criterion $j$.

Step 12. In the case of group decision-making, the final weights of the criteria are determined in the following manner:

$$
\begin{aligned}
& w_{j}^{*}=\left(\prod_{r=1}^{R} w_{j}^{n r}\right)^{1 / R}, \\
& w_{j}=\frac{w_{j}^{*}}{\sum_{j=1}^{n} w_{j}^{*}}
\end{aligned}
$$

where $w_{j}^{n r}$ denotes the weight of the criterion $j$ obtained from the respondent $r, R$ represents the number of the respondents, $w_{j}^{*}$ is the group weight of the criterion $j$ before the adjustment in order to fulfill the condition $\sum_{j=1}^{n} w_{j}=1$, and the $w_{j}$ is the final group weight of the criterion $j$. 
Popović G. et al.: Multiple criteria approach in the mining method selection

\section{Case study}

As we previously stated, the selection of an appropriate underground mining method is not simply tasked for mining engineers because it requires knowledge, experience, and competence. Besides, the problem additionally complicates the possibility of existence of a few methods that could be convenient for applying in particular case but only one of them would certainly enable maximum usage of the available potential. It is very unlikely that one person would be completely sure which alternative i.e. mining method is optimal for application in present conditions.

The reliability of the selected mining method increases in the case when the decision process involves a greater number of $D M$ s. Following that idea, the PIPRECIA-E method is used as a technique which is convenient for applying in the group decision environment. Besides, its procedure that predicts consistency checking in two ways contributes to the assurance that the final choice will be optimal.

The applicability of the proposed model is demonstrated through real case study relative to the Čukaru Peki deposit, situated in the Bor district in Serbia, that includes the Upper Zone of high-sulphidation epithermal mineralization and the Lower Zone of porphyry type of mineralization. The fact that, in this deposit, a probable grade of the Cu amounts $3.25 \%$, Au $2.06 \%$ and As $0.17 \%$ classifies it in the group of the reachest deposits in the world (Nevsun Resources Ltd, 2018). Until now, the pre-feasibility study for the mine development in the Upper Zone and basic resource assessment for the Lower Zone is done. For the purpose of this work, the optimal mining method for the Upper Zone of the Čukaru Peki will be selected because the more detailed pieces of information are currently available.

The evaluation process is based on 3 groups of criteria that involve 6 subcriteria. The list of criteria and sub-criteria are formed accordingly to the papers of the: Ataei et al. (2008), Naghadehi et al. (2009), Bogdanovic et al. (2012) and Yazdani-Chamzini, Yakchali, \& Zavadskas (2012). Three DMs, experienced mining engineers, are involved in the decision process. In order to avoid too complex numerical example, the DMs selected 6 sub-criteria from every group and using the domination method formed the final list of subcriteria. Besides, the DMs are familiar with the characteristics of the Upper Zone and, on that base, they estimated the given alternatives. In Table 1 we presented criteria, sub-criteria and mining methods that will be assessed. 
Popović G. et al.: Multiple criteria approach in the mining method selection

Table 1. Criteria, sub-criteria and mining methods

\begin{tabular}{|c|c|c|c|c|c|}
\hline & Criteria & & Sub-criteria & & Alternatives \\
\hline \multirow{6}{*}{$T_{1}$} & \multirow{6}{*}{$\begin{array}{l}\text { Technical } \\
\text { parameters }\end{array}$} & $T_{11}$ & Ore body thickness & \multirow{3}{*}{$A_{1}$} & \multirow{3}{*}{ Room and pilar } \\
\hline & & $T_{12}$ & Ore body shape & & \\
\hline & & $T_{13}$ & Ore body dip & & \\
\hline & & $T_{14}$ & Ore body size & \multirow{3}{*}{$A_{2}$} & \multirow{3}{*}{ Room and pillar with fill } \\
\hline & & $T_{15}$ & Ore body RMR & & \\
\hline & & $T_{16}$ & Ore body RSS & & \\
\hline \multirow{6}{*}{$P_{1}$} & \multirow{6}{*}{$\begin{array}{l}\text { Production } \\
\text { parameters }\end{array}$} & $P_{11}$ & Safety & \multirow{6}{*}{$A_{3}$} & \multirow{6}{*}{ Shrinkage stoping } \\
\hline & & $P_{12}$ & Environmental impact & & \\
\hline & & $P_{13}$ & Technology & & \\
\hline & & $P_{14}$ & Expert labour & & \\
\hline & & $P_{15}$ & Ventilation & & \\
\hline & & $P_{16}$ & Underground water & & \\
\hline \multirow{6}{*}{$E_{1}$} & \multirow{6}{*}{$\begin{array}{l}\text { Economic } \\
\text { parameters }\end{array}$} & $E_{11}$ & Operating cost & \multirow{3}{*}{$A_{4}$} & \multirow{3}{*}{ Cut and fill } \\
\hline & & $E_{12}$ & Capital cost & & \\
\hline & & $E_{13}$ & Reclamation cost & & \\
\hline & & $E_{14}$ & Mineral value & \multirow{3}{*}{$A_{5}$} & \multirow{3}{*}{ Sublevel caving } \\
\hline & & $E_{15}$ & Minerable ore tonnes & & \\
\hline & & $E_{16}$ & Ore body grades & & \\
\hline
\end{tabular}

Source: Ataei et al. (2008), Naghadehi et al. (2009), Bogdanovic et al. (2012) and YazdaniChamzini et al. (2012).

In Table 2 the local weights of the main criteria defined by the Eqs. (1)-(12) are presented. As can be seen, the responses from the DMs are completely consistent and acceptable.

Table 2. The local weights of the main criteria

\begin{tabular}{|c|c|c|c|c|c|}
\hline & $w_{j}^{\prime \prime 1}$ & $w_{j}^{\prime \prime 2}$ & $w_{j}^{\prime \prime 3}$ & $w_{j}^{*}$ & $w_{j}$ \\
\hline$T_{1}$ & 0.2817 & 0.3114 & 0.3333 & 0.3081 & 0.3084 \\
\hline$P_{1}$ & 0.3591 & 0.3443 & 0.3333 & 0.3454 & 0.3458 \\
\hline$E_{1}$ & 0.3591 & 0.3443 & 0.3333 & 0.3454 & 0.3458 \\
\hline$\rho$ & 1 & 1 & 1 & \multicolumn{3}{|c}{} \\
\cline { 1 - 4 } & & \multicolumn{5}{|c}{}
\end{tabular}

Source: Author's calculations

The obtained results show that considered criteria groups have almost equal importance for the DMs. 
Popović G. et al.: Multiple criteria approach in the mining method selection

The local weights of the sub-criteria from the group named „Technical parameters", obtained by using Eqs. (1)-(12), are presented in Table 3.

Table 3. The local weights of the sub-criteria - „Technical parameters“

\begin{tabular}{|c|c|c|c|c|c|}
\hline & $w_{j}^{\prime \prime 1}$ & $w_{j}^{\prime \prime 2}$ & $w_{j}^{\prime \prime}$ & $w_{j}^{*}$ & $w_{j}$ \\
\hline$T_{11}$ & 0.1162 & 0.1695 & 0.1383 & 0.1396 & 0.1420 \\
\hline$T_{12}$ & 0.0761 & 0.1534 & 0.1529 & 0.1213 & 0.1233 \\
\hline$T_{13}$ & 0.1083 & 0.1695 & 0.1529 & 0.1411 & 0.1434 \\
\hline$T_{14}$ & 0.1926 & 0.1534 & 0.1792 & 0.1743 & 0.1771 \\
\hline$T_{15}$ & 0.2534 & 0.1771 & 0.1884 & 0.2037 & 0.2071 \\
\hline$T_{16}$ & 0.2534 & 0.1771 & 0.1884 & 0.2037 & 0.2071 \\
\hline$\rho$ & 0.83 & 0.89 & 1 & \multicolumn{3}{l}{} \\
\hline
\end{tabular}

Source: Author's calculations

In the given case the high degree of the consistency of the responses is evident. As the most important sub-criteria $T_{15}$ - Ore body $R M R$ and $T_{16}$ - Ore body grades singled out.

Table 4 presents the local weights of the sub-criteria from the group "Production parameters". Given results are obtained in the previously explained way which will be used furthermore.

Table 4. The local weights of the sub-criteria - „Production parameters“

\begin{tabular}{|c|c|c|c|c|c|}
\hline & $w_{j}^{\prime \prime 1}$ & $w_{j}^{\prime \prime 2}$ & $w_{j}^{\prime \prime 3}$ & $w_{j}^{*}$ & $w_{j}$ \\
\hline$P_{11}$ & 0.1323 & 0.1759 & 0.1509 & 0.1520 & 0.1537 \\
\hline$P_{12}$ & 0.1073 & 0.1591 & 0.1231 & 0.1281 & 0.1296 \\
\hline$P_{13}$ & 0.1004 & 0.1759 & 0.1508 & 0.1386 & 0.1402 \\
\hline$P_{14}$ & 0.2200 & 0.1523 & 0.1667 & 0.1774 & 0.1795 \\
\hline$P_{15}$ & 0.2200 & 0.1684 & 0.2042 & 0.1963 & 0.1985 \\
\hline$P_{16}$ & 0.2200 & 0.1684 & 0.2042 & 0.1963 & 0.1985 \\
\hline$\rho$ & 0.97 & 0.94 & 0.94 & & \\
\hline
\end{tabular}

Source: Author's calculations

The consistency rate is again on the satisfying level and the highest local weight has the sub-criteria $P_{15}$-Ventilation and $P_{16}$ - Underground water.

Table 5 shows the results for the sub-criteria that belongs to the group "Economic parameters". 
Popović G. et al.: Multiple criteria approach in the mining method selection

Table 5. The local weights of the sub-criteria - „Economic parameters“

\begin{tabular}{|c|c|c|c|c|c|}
\hline & $w_{j}^{\prime \prime 1}$ & $w_{j}^{\prime \prime 2}$ & $w_{j}^{\prime \prime 3}$ & $w_{j}^{*}$ & $w_{j}$ \\
\hline$E_{11}$ & 0.0798 & 0.1429 & 0.1334 & 0.1150 & 0.1172 \\
\hline$E_{12}$ & 0.0894 & 0.1580 & 0.1233 & 0.1203 & 0.1226 \\
\hline$E_{13}$ & 0.0894 & 0.1580 & 0.1508 & 0.1287 & 0.1311 \\
\hline$E_{14}$ & 0.2184 & 0.1747 & 0.1975 & 0.1960 & 0.1998 \\
\hline$E_{15}$ & 0.2100 & 0.1832 & 0.1975 & 0.1966 & 0.2004 \\
\hline$E_{16}$ & 0.3129 & 0.1832 & 0.1975 & 0.2246 & 0.2288 \\
\hline$\rho$ & 0.86 & 0.89 & 1 & \multicolumn{3}{|c}{} \\
\cline { 1 - 4 } & & \multicolumn{3}{|c}{}
\end{tabular}

Source: Author's calculations

The obtained results confirmed that the DMs were not contradictory with their decisions. In this case, according to the results, the greatest local weight has the sub-criteria $E_{16}$ - Ore body grades.

Table 6 demonstrates the global weights of the considered sub-criteria.

Table 6. The global weights of the sub-criteria

\begin{tabular}{|c|c|c|c|c|}
\hline Criteria & $\begin{array}{c}\text { Global weight of } \\
\text { the criteria }\end{array}$ & Sub-criteria & $\begin{array}{l}\text { Local weight of } \\
\text { the sub-criteria }\end{array}$ & $\begin{array}{l}\text { The global weight } \\
\text { of the sub-criteria }\end{array}$ \\
\hline \multirow{6}{*}{$T_{1}$} & \multirow{6}{*}{0.3084} & $T_{11}$ & 0.1420 & 0.0438 \\
\hline & & $T_{12}$ & 0.1233 & 0.0380 \\
\hline & & $T_{13}$ & 0.1434 & 0.0442 \\
\hline & & $T_{14}$ & 0.1771 & 0.0546 \\
\hline & & $T_{15}$ & 0.2071 & 0.0639 \\
\hline & & $T_{16}$ & 0.2071 & 0.0639 \\
\hline \multirow{6}{*}{$P_{1}$} & \multirow{6}{*}{0.3458} & $P_{11}$ & 0.1537 & 0.0532 \\
\hline & & $P_{12}$ & 0.1296 & 0.0448 \\
\hline & & $P_{13}$ & 0.1402 & 0.0485 \\
\hline & & $P_{14}$ & 0.1795 & 0.0621 \\
\hline & & $P_{15}$ & 0.1985 & 0.0687 \\
\hline & & $P_{16}$ & 0.1985 & 0.0687 \\
\hline \multirow{6}{*}{$E_{1}$} & \multirow{6}{*}{0.3458} & $E_{11}$ & 0.1172 & 0.0405 \\
\hline & & $E_{12}$ & 0.1226 & 0.0424 \\
\hline & & $E_{13}$ & 0.1311 & 0.0453 \\
\hline & & $E_{14}$ & 0.1998 & 0.0691 \\
\hline & & $E_{15}$ & 0.2004 & 0.0693 \\
\hline & & $E_{16}$ & 0.2288 & 0.0791 \\
\hline
\end{tabular}

Source: Author's calculations 
Popović G. et al.: Multiple criteria approach in the mining method selection

Every of the considered alternative is estimated relative to each of the subcriteria involved in the decision process. Based on that evaluation and on global weights of the sub-criteria, the overall importance of the underground mining methods is calculated regarding every separate group of the subcriteria. The results are shown in the Table 7, 8 and 9, respectively.

Table 7. The overall importance of each mining method according to the sub-criteria - „Technical parameters“

\begin{tabular}{|c|c|c|c|c|c|c|}
\hline & $T_{1}$ & $T_{2}$ & $T_{3}$ & $T_{4}$ & $T_{5}$ & $T_{6}$ \\
\hline$A_{1}$ & 0.0094 & 0.0077 & 0.0092 & 0.0107 & 0.0130 & 0.0134 \\
\hline$A_{2}$ & 0.0101 & 0.0085 & 0.0100 & 0.0122 & 0.0134 & 0.0144 \\
\hline$A_{3}$ & 0.0096 & 0.0083 & 0.0096 & 0.0122 & 0.0146 & 0.0146 \\
\hline$A_{4}$ & 0.0101 & 0.0091 & 0.0101 & 0.0127 & 0.0146 & 0.0146 \\
\hline$A_{5}$ & 0.0099 & 0.0090 & 0.0107 & 0.0134 & 0.0161 & 0.0146 \\
\hline
\end{tabular}

Source: Author's calculations

Table 8. The overall importance of each mining method according to the sub-criteria - „Production parameters“

\begin{tabular}{|c|c|c|c|c|c|c|}
\hline & $P_{1}$ & $P_{2}$ & $P_{3}$ & $P_{4}$ & $P_{5}$ & $P_{6}$ \\
\hline$A_{1}$ & 0.0103 & 0.0078 & 0.0084 & 0.0117 & 0.0128 & 0.0135 \\
\hline$A_{2}$ & 0.0110 & 0.0093 & 0.0098 & 0.0121 & 0.0137 & 0.0140 \\
\hline$A_{3}$ & 0.0107 & 0.0091 & 0.0094 & 0.0125 & 0.0138 & 0.0135 \\
\hline$A_{4}$ & 0.0107 & 0.0096 & 0.0099 & 0.0125 & 0.0138 & 0.0131 \\
\hline$A_{5}$ & 0.0104 & 0.0090 & 0.0110 & 0.0134 & 0.0146 & 0.0145 \\
\hline
\end{tabular}

Source: Author's calculations

Table 9. The overall importance of each mining method according to the sub-criteria - „Economic parameters"

\begin{tabular}{|c|c|c|c|c|c|c|}
\hline & $E_{1}$ & $E_{2}$ & $E_{3}$ & $E_{4}$ & $E_{5}$ & $E_{6}$ \\
\hline$A_{1}$ & 0.0079 & 0.0087 & 0.0091 & 0.0138 & 0.0125 & 0.0157 \\
\hline$A_{2}$ & 0.0076 & 0.0086 & 0.0091 & 0.0147 & 0.0129 & 0.0159 \\
\hline$A_{3}$ & 0.0079 & 0.0081 & 0.0091 & 0.0139 & 0.0139 & 0.0157 \\
\hline$A_{4}$ & 0.0091 & 0.0087 & 0.0091 & 0.0139 & 0.0155 & 0.0161 \\
\hline$A_{5}$ & 0.0080 & 0.0083 & 0.0091 & 0.0128 & 0.0145 & 0.0158 \\
\hline
\end{tabular}

Source: Author's calculations 
Popović G. et al.: Multiple criteria approach in the mining method selection

The overall results and final ranking of the considered mining methods are presented in Table 10.

Table 10. The final rank of the mining methods

\begin{tabular}{|c|c|c|}
\hline Mining method & Priority & Rank \\
\hline$A_{1}$ & 0.1956 & 5 \\
\hline$A_{2}$ & 0.2072 & 3 \\
\hline$A_{3}$ & 0.2062 & 4 \\
\hline$A_{4}$ & 0.2132 & 2 \\
\hline$A_{5}$ & 0.2150 & 1 \\
\hline
\end{tabular}

Source: Author's calculations

As the final results show, the best-ranked alternative is $A_{5}$ - Sublevel caving. Noting the characteristics of the Upper Zone of the Čukaru Peki, this choice is totally justified. Aforementioned mining method will enable access to the higher grades of the mineralization and better use of the available metals in the given deposit.

\section{Conclusion}

An extremely important decision for the mining engineers is the selection of the appropriate mining method because it seriously affects the future performance of a certain mine. The threat of involving overly subjectivity could be overcome by introducing group decision-making. Besides, relying on the selection procedure of the greater number of criteria increases the chance of making an optimal decision.

In this paper, the PIPRECIA-E method in the group decision environment is applied for the underground method selection. In order to present the applicability of the proposed methodology, we used the illustrative example connected to the mining method selection for the exploitation of the Čukaru Peki Upper Zone. Three DMs estimated 5 mining methods against 3 groups of criteria and 18 sub-criteria in total. The obtained results are in lieu with given conditions of considered deposit and they are entirely reliable and justified.

The PIPRECIA-E method proved that it is very convenient for applying in cases when there are several $D M$ s. The reliability of received responses is checked in two ways: (1) by a bidirectional approach in the evaluation of the given set of criteria; (2) and by using Spearman's correlation. Thereby, by checking the consistency of the obtained responses twice, the possibility of wrong decisions decreases. This is the advantage of the PIPRECIA-E method relative to the SWARA method. Also, by predicting the reliability checking, this 
method could be considered equally reliable as widely well-known AHP method. Besides, it has advanced relative to the AHP because the procedure is somewhat simpler than in the AHP method.

As we earlier stated, the selection of the appropriate set of criteria is a very important phase in the decision-making process. In this case, the list of the evaluation criteria is formed on the base of the sets proposed in the papers that considered same topic (Ataei et al., 2008; Naghadehi et al., 2009; Bogdanovic et al., 2012; Yazdani-Chamzini et al., 2012). The main criteria groups are pointed to the: technical, production and economic parameters. Involving a different kind of criteria will give a complete and clear picture to DMs about aspects important for the optimal mining method selection.

The main deficiency of this paper reflects through neglecting of uncertainty. Some authors, that examined the problem of mining method selection, proposed the application of the extensions of the MCDM methods (Karadogan et al., 2008; Namin, Shahriar, Bascetin, \& Ghodsypour, 2012; Dehghani, Siami, \& Haghi, 2017; Liang, Zhao, \& Hong, 2018). By introducing the fuzzy, grey or neutrosophic numbers, the vagueness of the environment would be acknowledged in the higher degree and the possibility of making a wrong decision would be minimized. Also, the procedure of the PIPRECIA-E method could be esteemed as complex because the list of criteria should be evaluated from the first to the last and vice-versa. But, although this fact could not be denied, this kind of procedure leads to trustful results.

The proposed methodology shows that it is quite useful for application in the area of the underground mining method selection. Besides, it could be used for the resolving of other problems in the mine production such as equipment selection (Rahimdel \& Karamoozian, 2014; Yavuz, 2015b), grinding circuit selection (Stanujkic, Magdalinovic, Milanovic, Magdalinovic, \& Popovic, 2014; Stanujkic, Zavadskas, Karabasevic, Milanovic, \& Maksimovic, 2019b) and transportation system selection (Gupta, Mehlawat, Aggarwal, \& Charles, 2018). The potentials of the PIPRECIA-E method are not fully examined so there is enough room for testing its possibilities and proposing appropriate extensions.

\section{References}

Alpay, S., \& Yavuz, M. (2007). A decision support system for underground mining method selection. Proceedings of the International Conference on Industrial, Engineering and Other Applications of Applied Intelligent Systems (pp. 334-343). Springer, Berlin, Heidelberg. https://doi.org/10.1007/978-3-540-73325-6 33.

Alpay, S., \& Yavuz, M. (2009). Underground mining method selection by decision making tools. Tunnelling and Underground Space Technology, 24(2), 173-184. https://doi.org/10.1016/..tust.2008.07.003. 
Popović G. et al.: Multiple criteria approach in the mining method selection

Ataei, M., Jamshidi, M., Sereshki, F., \& Jalali, S.M.E. (2008). Mining method selection by AHP approach. Journal of the Southern African Institute of Mining and Metallurgy, 108(12), 741-749.

Ataei, M., Shahsavany, H., \& Mikaeil, R. (2013). Monte Carlo Analytic Hierarchy Process (MAHP) approach to selection of optimum mining method. International Journal of Mining Science and Technology, 23(4), 573-578. https://doi.org/10.1016/j.ijmst.2013.07.017.

Bitarafan, M. R., \& Ataei, M. (2004). Mining method selection by multiple criteria decision making tools. Journal of the Southern African Institute of Mining and Metallurgy, 104(9), 493-498.

Bogdanovic, D., Nikolic, D., \& Ilic, I. (2012). Mining method selection by integrated AHP and PROMETHEE method. Anais da Academia Brasileira de Ciências, 84(1), 219-233. http://dx.doi.org/10.1590/S0001-37652012005000013.

Dehghani, H., Siami, A., \& Haghi, P. (2017). A new model for mining method selection based on grey and TODIM methods. Journal of Mining and Environment, 8(1), 49-60. https://doi.org/10.22044/jme.2016.626.

Gupta, S., \& Kumar, U. (2012). An analytical hierarchy process (AHP)-guided decision model for underground mining method selection. International Journal of Mining, Reclamation and Environment, 26(4), 324-336. https://doi.org/10.1080/17480930.2011.622480.

Gupta, P., Mehlawat, M. K., Aggarwal, U., \& Charles, V. (2018). An integrated AHPDEA multi-objective optimization model for sustainable transportation in mining industry. Resources Policy (In Press). https://doi.org/10.1016/j.resourpol.2018.04.007.

Karadogan, A., Kahriman, A., \& Ozer, U. (2008). Application of fuzzy set theory in the selection of underground mining method. Journal of The Southern African Institute of Mining and Metallurgy, 108(2), 73-79.

Karimnia, H., \& Bagloo, H. (2015). Optimum mining method selection using fuzzy analytical hierarchy process-Qapiliq salt mine, Iran. International Journal of Mining Science and Technology, 25(2), 225-230. https://doi.org/10.1016/j.ijmst.2015.02.010.

Keršuliene, V., Zavadskas, E. K., \& Turskis, Z. (2010). Selection of rational dispute resolution method by applying new Step-wise Weight Assessment Ratio Analysis (SWARA). Journal of Business Economics and Management, 11(2), 243-258. https://doi.org/10.3846/ibem.2010.12.

Liang, W., Zhao, G., \& Hong, C. (2018). Selecting the optimal mining method with extended multi-objective optimization by ratio analysis plus the full multiplicative form (MULTIMOORA) approach. Neural Computing and Applications, 1-16. https://doi.org/10.1007/s00521-018-3405-5.

Liu, A. H., Dong, L., \& Dong, L. J. (2010). Optimization model of unascertained measurement for underground mining method selection and its application. Journal of Central South University of Technology,17(4), 744-749. https://doi.org/10.1007/s11771-010-0550-0.

Mahase, M. J., Musingwini, C., \& Nhleko, A. S. (2016). A survey of applications of multi-criteria decision analysis methods in mine planning and related case studies. Journal of the Southern African Institute of Mining and Metallurgy, 116(11), 1051-1056. http://dx.doi.org/10.17159/2411-9717/2016/v116n11a7.

Mardani, A., Jusoh, A., Nor, K., Khalifah, Z., Zakwan, N., \& Valipour, A. (2015). Multiple criteria decision-making techniques and their applications - a review of 
Popović G. et al.: Multiple criteria approach in the mining method selection

the literature from 2000 to 2014. Economic Research-Ekonomska Istraživanja, 28(1), 516-571. https://doi.org/10.1080/1331677X.2015.1075139.

Milosavljević, M., Bursaća, M., \& Tričković, G. (2018). Selection of the railroad container terminal in Serbia based on multi criteria decision-making methods. Decision Making: Applications in Management and Engineering, 1(2), 1-15. https://doi.org/10.31181/dmame180101p.

Naghadehi, M. Z., Mikaeil, R., \& Ataei, M. (2009). The application of fuzzy analytic hierarchy process (FAHP) approach to selection of optimum underground mining method for Jajarm Bauxite Mine, Iran. Expert Systems with Applications, 36(4), 8218-8226. https://doi.org/10.1016/j.eswa.2008.10.006.

Namin, F. S., Shahriar, K., Bascetin, A., \& Ghodsypour, S. H. (2012). FMMSIC: a hybrid fuzzy based decision support system for MMS (in order to estimate interrelationships between criteria). Journal of the Operational Research Society, 63(2), 218-231. https://doi.org/10.1057/jors.2011.24.

Nevsun Resources Ltd (2018). NI43-101 Technical Report - Pre-Feasibility Study for the Timok Project, Serbia. Bor, Serbia: Jakubec, J., Pittuck, M., Samoukovic, M., MacSporran, G., Manojlovic, P., Bunyard, M., Duinker, R., \& Sucharda, M.

Pamučar, D., Lukovac, V., Božanić, D., \& Komazec, N. (2018). Multi-criteria FUCOMMAIRCA model for the evaluation of level crossings: case study in the Republic of Serbia. Operational Research in Engineering Sciences: Theory and Applications, 1(1), 108-129. https://doi.org/10.31181/oresta190101s.

Popović, G., \& Mihajlović, D. (2018). An MCDM approach to tourism project evaluation: The Upper Danube basin case. Thematic Proceedings "Modern Management Tools and Economy of Tourism Sector in Present Era" (pp. 129143). UDECOM. Belgrade, Serbia. https://doi.org/10.31410/tmt.2018.129.

Rahimdel, M. J., \& Karamoozian, M. (2014). Fuzzy TOPSIS method to primary crusher selection for Golegohar Iron Mine (Iran). Journal of Central South University, 21(11), 4352-4359. https://doi.org/10.1007/s11771-014-2435-0.

Saaty, T. L. (1980). The Analytic Hierarchy Process: planning, priority setting, resource allocation. New York: McGraw-Hill.

Samimi Namin, F., Shahriar, K., Ataee-Pour, M., \& Dehghani, H. (2008). A new model for mining method selection of mineral deposit based on fuzzy decision making. Journal of the Southern African Institute of Mining and Metallurgy, 108(7), 385395.

Stanujkic, D., Magdalinovic, N., Milanovic, D., Magdalinovic, S., \& Popovic, G. (2014). An efficient and simple multiple criteria model for a grinding circuit selection based on MOORA method. Informatica, 25(1), 73-93.

Stanujkic, D., Zavadskas, E. K., Karabasevic, D., Smarandache, F., \& Turskis, Z. (2017). The use of the Plvot Pairwise RElative Criteria Importance Assessment method for determining the weights of criteria. Romanian Journal of Economic Forecasting, 20(4), 116-133.

Stanujkic, D., Karabasevic, D., \& Cipriana, S. (2018). An application of the PIPRECIA and WS PLP methods for evaluating website quality in hotel industry. Quaestus, 12, 190-198.

Stanujkic, D., Karabasevic, D., Zavadskas, E. K., Smarandache, F., \& Cavallaro, F. (2019a). An approach to determining customer satisfaction in traditional Serbian restaurants. Entrepreneurship and Sustainability Issues, 6(3), 1127-1138. http://doi.org/10.9770/jesi.2019.6.3(5). 
Popović G. et al.: Multiple criteria approach in the mining method selection

Stanujkic, D., Zavadskas, E. K., Karabasevic, D., Milanovic, D., \& Maksimovic, M. (2019b). An approach to solving complex decision-making problems based on IVIFNs: A case of comminution circuit design selection. Minerals Engineering, 138, 70-78. https://doi.org/10.1016/j.mineng.2019.04.036.

Stević, Ž., Stjepanović, Ž., Božičković, Z., Das, D., \& Stanujkić, D. (2018). Assessment of Conditions for Implementing Information Technology in a Warehouse System: A Novel Fuzzy PIPRECIA Method. Symmetry, 10(11), 586. https://doi.org/10.3390/sym10110586.

Velasquez, M., \& Hester, P. T. (2013). An analysis of multi-criteria decision making methods. International Journal of Operations Research, 10(2), 56-66.

Vesković, S., Stević, Ž., Stojić, G., Vasiljević, M., \& Milinković, S. (2018). Evaluation of the railway management model by using a new integrated model DELPHISWARA-MABAC. Decision Making: Applications in Management and Engineering, 1(2), 34-50. https://doi.org/10.31181/dmame180101p.

Yavuz, M. (2015a). The application of the analytic hierarchy process (AHP) and Yager's method in underground mining method selection problem. International Journal of Mining, Reclamation and Environment, 29(6), 453-475. https://doi.org/10.1080/17480930.2014.895218.

Yavuz, M. (2015b). Equipment selection based on the AHP and Yager's method. Journal of the Southern African Institute of Mining and Metallurgy, 115(5), 425433.

Yazdani-Chamzini, A., Yakchali, S. H., \& Zavadskas, E. K. (2012). Using an integrated MCDM model for mining method selection in presence of uncertainty. Economic Research-Ekonomska Istraživanja, 25(4), 869-904.

Zavadskas, E.K., Turskis, Z., \& Kildienè, S. (2014). State of art surveys of overviews on MCDM/MADM methods. Technological and Economic Development of Economy, 20(1), 165-179. https://doi.org/10.3846/20294913.2014.892037. 